\title{
Investigation of Self-Esteem Levels of the Candidates Participated in Special Talent Exam
}

\section{Ilker Ozmutlu' 1 Erhan Kara ${ }^{\star \star}$}

Tekirdă̆ Namık Kemal University, School of Physical Education and Sports, Tekirdağ, Turkey. 'Email:iozmutlu@nku.edu.trTel:90+05059184849

2Email:ekara@nku.edu.trTel:+905547873925

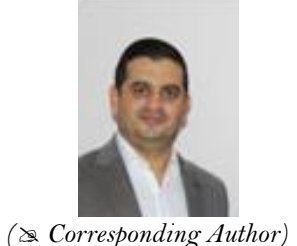

\section{Abstract}

The purpose of study is to investigate the self-esteem levels of the candidates who participated in the special talent exam (STE) through various variables. The study group consists of 129 female and 649 male, 778 participants in total attending STE conducted by Tekirdağ Namik Kemal University School of Physical Education and Sport in 2018. In the research conducted with the relational screening model method, personal information form developed by the researcher and "Rosenberg Self-Esteem Scale" developed by Rosenberg (1965) whose Turkish adaptation studies were carried out by Cuhadaroğlu (1986) have been used in order to determinate self-esteem levels of the participants in STE. The scale consists of 10 items in 4 point Likert type. Cronbach Alpha coefficient for reliability is .81. At the end of the study; it was found that there was no significant relationship between the self-esteem levels of the candidates and gender variable, TYT (Basic Proficiency Test) score, geographical region of residence and the high school type of graduation. A positive and low level of relationship was found between the self-esteem levels of the candidates and the sports branch variable.

Keywords: Self-esteem, Special talent exam, Candidate, Physical education, Sport, Self-respect.

Citation | Ilker Ozmutlu; Erhan Kara (2020). Investigation of SelfEsteem Levels of the Candidates Participated in Special Talent Exam. Asian Journal of Education and Training, 6(3): 421-425. History:

Received: 7 April 2020

Revised: 12 May 2020

Accepted: 15 June 2020

Published: 22 June 2020

Licensed: This work is licensed under a Creative Commons Attribution 3.0 License (oc)

Publisher: Asian Online Journal Publishing Group
Acknowledgement: Both authors contributed to the conception and design of the study

Funding: This study received no specific financial support.

Competing Interests: The authors declare that they have no conflict of interests.

Transparency: The authors confirm that the manuscript is an honest, accurate, and transparent account of the study was reported; that no vital features of the study have been omitted; and that any discrepancies from the features of the study have been omitted;
study as planned have been explained.

Ethical: This study follows all ethical practices during writing.

\section{Contents}

1. Introduction

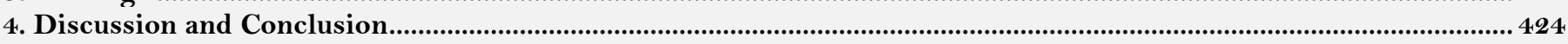

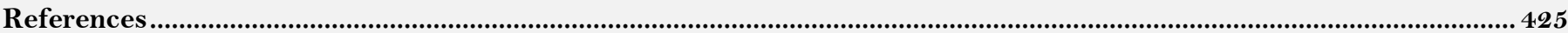




\section{Contribution of this paper to the literature}

This study was researched because the number of studies investigating the relationship between the self-esteem levels of the candidates who participated in the special talent exam was insufficient. So, this issue is thought to be better understood and it is estimated to be useful for future studies.

\section{Introduction}

Self-esteem is the judgement that the individual passes on and the attitude that he/she develops about himself as a result of evaluating himself as an object. This attitude, expressed in terms such as self-respect, self-esteem, selfworth, can be considered as a top concept, which is depicted with or includes concepts such as self-esteem, selfacceptance (Kuzgun, 2000). Self-esteem expresses one's self-confidence and satisfaction with himself; is how one thinks and feels about himself (Aslan, 2006). Although there are different points of view about self-esteem, selfesteem is defined as "an individual's feeling of self-worth, seeing himself as an adequate person, feelings about selfacceptance or self-respect" (Coopersmith, 1967; Crocker \& Major, 1989; Rosenberg, 1965). As it has been seen in the definitions of self-esteem, the individual's self-perception, emotion, trust, self-evaluation criteria, and relationships with the environment constitute the self-esteem of the individual. The individual's attitudes that confirm or do not approve of selfness and whether the individual finds himself skilled, important, successful and valuable determine the level of self-esteem. When the individual acts in harmony with his selfness, he feels safe, sufficient and valuable (Ciğdemoğlu, 2006).

It has been stated in the literature that self-esteem is an important factor that affects the psychosocial status and social lives of individuals (Salmivalli, Kaukiainen, Kaistaniemi, \& Lagerspetz, 1999). Self-esteem affects social, emotional, cognitive and academic lives of the individuals. Self-esteem which is a prerequisite for a healthy personality plays an important role in making the person an active and participatory member of society. Effective participation in society also brings personal success and happiness (Güloğlu \& Aydın, 2001). The individual having high self-esteem evaluates himself positively, avoids aggressive attitudes and feels good. He also discovers his weaknesses and tries to overcome them. An individual having low self-esteem is weak in self-confidence. These people are addicted to other individuals and become embarrassed (Reisoğlu, Gedik, \& Göktaş, 2013). In accordance with this information, the aim of this study is to examine self-esteem levels of the candidates participating in the special talent exam through various variables.

\section{Material and Method}

\subsection{Research Method}

The study has been conducted through Relational Screening Model. Screening Models are appropriate for researches aiming to describe a situation in the past or at present as so (Karasar, 2005). Relational screening models, on the other hand, are considered appropriate for this research since they are used for research models aiming to determine the presence of co-exchange between two and more variables.

\subsection{Research Group}

The study group consists of 129 female and 649 male, 778 participants in total participating voluntarily among 1100 candidates attending STE conducted by Tekirdağ Namı Kemal University School of Physical Education and Sport in 2018.

\subsection{Data Collection Tool}

Rosenberg Self-Esteem Scale was used to determine the self-esteem levels of the candidates who participated in the special talent exam. The scale was developed by Rosenberg (1965). The Turkish adaptation studies of the scale were carried out by Cuhadaroğlu (1986). The 4-point Likert type consists of 10 items. Total scores obtained from all items range from 0-40. High scores indicate that individuals have a high level of self-esteem (Ko, Yen, Chen, Chen, \& Yen, 2005). Cronbach Alpha coefficient for reliability is .81. Cronbach Alpha coefficient in our study is .85.

\subsection{Data Analysis}

When One-Sample Kolmogorov-Smirnov Test, which shows the self-esteem levels of the candidates who participated in the special talent exam, was examined, it was found that the data were not suitable for normal distribution. Therefore, Mann-Whitney U test and Kruskal-wallis tests were used in accordance with the analysis obtained from Non-Parametric tests and the level of significance was taken as $(p<0.05)$.

\section{Findings}

Table-1. The results of the Mann-Whitney U test showing self-esteem levels according to the gender variable of the research group.

\begin{tabular}{l|l|c|c|c|c|c}
\hline Variables & $\mathbf{N}$ & Mean Rank & Rank Sum & U & P & Cohen's d \\
\hline Male & 129 & 400,56 & 51672,50 & 40433,500 & \multirow{2}{*}{, $537^{*}$} & 0,000489 \\
\cline { 1 - 4 } Female & 649 & 387,30 & 251358,50 & & & \\
\hline Note: ${ }^{*} p>0,05$.
\end{tabular}

Considering Table 1, it has been found that there is no significant difference between the gender variable and self-esteem levels of the research group $(\mathrm{U}=40433,500 \mathrm{p}=0,537)$. When we look at Cohen's d effect size, it has been concluded that the gender variable of the research group has a low impact on the self-esteem levels of individuals. 
Table-2. The results of the Kruskal-wallis tests showing self-esteem levels according to the TYT (Basic Proficiency Test) Score variable of the research group.

\begin{tabular}{|c|c|c|c|c|c|c|}
\hline Variables & $\mathbf{N}$ & Mean Rank & Sd & $\mathbf{X}^{2}$ & $\mathbf{P}$ & Cohen's d \\
\hline 180-200 Points & 375 & 393,26 & \multirow{5}{*}{4} & \multirow{5}{*}{4,289} & \multirow{5}{*}{$0,368^{*}$} & \multirow[t]{5}{*}{0,00551} \\
\hline 201-220 Points & 224 & 383,65 & & & & \\
\hline 221-240 Points & 123 & 385,93 & & & & \\
\hline 241-260 Points & 27 & 334,20 & & & & \\
\hline 261 Points & 29 & 452,69 & & & & \\
\hline
\end{tabular}

According to the Table 2 , no significant difference has been found between the TYT score variable and selfesteem levels of the research group $(\mathrm{X} 2=4.289 \mathrm{p}=0.368)$. When we look at the effect size of Cohen's $\mathrm{d}$, it has been concluded that the TYT score variable of the research group has a low impact on the self-esteem levels of individuals.

Table-3. The results of the Kruskal-wallis tests showing self-esteem levels according to the place of residence variable of the research group.

\begin{tabular}{|c|c|c|c|c|c|c|}
\hline Variables & $\mathbf{N}$ & Mean Rank & Sd & $\mathrm{X}^{2}$ & $\mathbf{P}$ & Cohen's d \\
\hline Village - Town & 57 & 435,81 & \multirow{4}{*}{3} & \multirow{4}{*}{3,024} & \multirow{4}{*}{$0,388^{*}$} & \multirow{4}{*}{0,00389} \\
\hline District & 211 & 381,52 & & & & \\
\hline City & 122 & 396,50 & & & & \\
\hline Metropolis & 388 & 384,84 & & & & \\
\hline
\end{tabular}

Note: *p $>0,05$.

In the Table 3, no significant difference has been found between the place of residence variable and self-esteem levels of the research group $\left(\mathrm{X}_{2}=3.024 \mathrm{p}=0.388\right)$. When we look at the effect size of Cohen's $\mathrm{d}$, it has been revealed that the place of residence variable of the candidates participating in the special talent exam has a low impact on the self-esteem levels of individuals.

Table-4. The results of the Kruskal-wallis tests showing self-esteem levels according to the High School type of graduation variable of the research group.

\begin{tabular}{|c|c|c|c|c|c|c|}
\hline Variables & $\mathbf{N}$ & Mean Rank & Sd & $\mathrm{X}^{2}$ & $\mathbf{P}$ & Cohen's d \\
\hline General High School & 43 & 363,13 & \multirow{6}{*}{5} & \multirow{6}{*}{7,483} & \multirow{6}{*}{$0,187^{*}$} & \multirow{6}{*}{0,00963} \\
\hline Vocational High School & 234 & 408,72 & & & & \\
\hline Anatolian High School & 338 & 381,21 & & & & \\
\hline Science High School & 1 & 39,00 & & & & \\
\hline Sports High School & 59 & 353,97 & & & & \\
\hline Other High Schools & 103 & 407,79 & & & & \\
\hline
\end{tabular}

Note: *p $>0,05$

Considering the Table 4, no significant difference has been found between the High School Type of graduation variable and self-esteem levels of the research group $\left(\mathrm{X}_{2}=7,483 \mathrm{p}=0,187\right)$. When we look at the effect size of Cohen's d, it has been revealed that the High School Type of graduation variable of the candidates participating in the special talent exam has a low impact on the self-esteem levels of individuals.

Table-5. The results of the Kruskal-wallis tests showing self-esteem levels according to the branch variable of the research group.

\begin{tabular}{|c|c|c|c|c|c|c|c|}
\hline Variables & $\mathbf{N}$ & Mean Rank & Sd & $\mathrm{X}^{2}$ & $\mathbf{P}$ & Significant Difference & Cohen's d \\
\hline Team Sports & 369 & 370,25 & \multirow{3}{*}{2} & \multirow{3}{*}{13,496} & \multirow{3}{*}{$0,001^{*}$} & \multirow{3}{*}{$\begin{array}{l}1-3 \\
2-3\end{array}$} & \multirow{3}{*}{0,0173} \\
\hline Individual Sports & 215 & 376,80 & & & & & \\
\hline No Branch & 194 & 440,19 & & & & & \\
\hline
\end{tabular}

In the Table 5, a significant difference has been found between self-esteem levels and the branch variable of the research group $\left(\mathrm{X}_{2}=7,483 \mathrm{p}=0,001\right)$. Considering the mean ranks, self-esteem levels of the candidates with no branch have been higher than those doing team sports and individual sports.

When we look at the effect size of Cohen's d, it has been revealed that the branch variable of the candidates participating in the special talent exam has a moderate impact on the self-esteem levels of the individuals.

Table-6. The results of correlation analysis tests between self-esteem levels of the research group and Gender, TYT Scores, Place of Residence variable, High School Type of Graduation and Sport Branch.

\begin{tabular}{l|c|c|c|c|c|c}
\hline \multicolumn{2}{l|}{ Variable } & Gender & TYT Score & Place of Residence & $\begin{array}{c}\text { High School Type of } \\
\text { Graduation }\end{array}$ & Sport Branch \\
\hline \multirow{3}{*}{ Self-Esteem } & $\mathrm{r}$ &,- 022 &,- 010 &,- 027 &,- 021 &, 113 \\
\cline { 2 - 7 } & $\mathrm{p}$ &, 537 &, 780 &, 450 &, 567 &, $002^{*}$ \\
\cline { 2 - 7 } & $\mathrm{N}$ & 778 & 778 & 778 & 778 & 778 \\
\hline
\end{tabular}

Note: $* \mathrm{p}<0,05$.

In the Table 6, considering the correlation analysis test results between self- esteem levels of the research group and Gender, TYT Scores, Place of Residence variable, High School Type of Graduation and Sport Branch, it has been found that there is no significant relationship between self-esteem levels and Gender variable, TYT (Basic Proficiency Test) score variable, geographical region of residence variable and high school type of graduation variable. A positive low level significant relationship has been found between self-esteem levels of the candidates and sport branch variable. 


\section{Discussion and Conclusion}

A significant difference has not been found between the gender variable of the research group and their selfesteem levels. In these premises, it can be stated that gender variable of the research group has no impact on selfesteem levels. When similar studies are examined, the results of the study conducted by Karakaya, Coşkun, and A ̆gaoğlu (2006) and the results of the study conducted by Reisoğlu et al. (2013) show similarity with our findings. On the other hand, some similar studies have revealed different results. The results of the studies conducted by Ko et al. (2005) and Leung (2004) have revealed that self-esteem levels of the female participants are significantly higher than the male participants. On the contrary, Güçray (2001) has determined in his study that self-esteem levels of the male participants are higher than the female participants.

In the studies carried out on self-esteem level, it has been seen that study results differ in terms of gender variable. As a reason for these differences it can be said that it is caused by many factors such as diversity of measurement tools, characteristics of research groups, cultural differences and scope of research.

As a result of the research, it can be thought that the reason that no difference has been seen between male and female participants is due to some reasons such as the fact that both women and men benefit from equal opportunities in all areas, gender is not at the forefront in gaining status and dignity in society. As a matter of fact, (Twenge \& Campbell, 2002) have stated that the woman started to be active in every field of life especially after having entered the business life, operates in the same lines of business as men, nevertheless, the male's status has not changed and even has lost his role; as a result, self-esteem of women has improved.

No significant difference was found between the TYT score variable and self-esteem levels of the research group. According to this result, it can be said that there is no relationship between the academic achievement of the candidates who take the talent exam and their self-esteem levels. The results of some similar studies do not coincide with our findings. It is seen in general that the candidates with high academic success have also high selfesteem levels. According to O'Malley and Bachman (1983) have observed that a positive relationship between the child's self-esteem and academic ability and school success continues until the end of high school and then there is also a positive relationship between self-esteem and professional position. As a result of the study conducted by (Arseven, 1986) a high level of positive correlation was found in the research on the relationship between students' academic achievement and self-confidence. Yenidünya. (2005); Inanç (1997) have reached similar conclusions in the study results and reached the conclusion that academic success has a direct relationship with self-esteem. In other words, if the student's self-confidence is insufficient, his academic success is also insufficient (Soner, 1995).

The reason why our research result differs from similar studies in the literature is that as special talent exams are a system aiming to feature personal skills and abilities prior to academic success, it can be said that academic success keeps in the background or has less effect in special talent exams considering that the candidates participating in these exams have high self-esteem levels and are self-confident individuals.

No significant difference was found between the place of residence variable of the research group and the levels of self-esteem. According to this result, it can be said that the settlement of the participants do not have an impact on self-esteem levels. When the results of similar studies are analyzed, our study differs with the findings of the study conducted by Yılmaz (2000) while it shows similarity with the findings of the study conducted by Cengil (2009); Altunbaş (2006); Baybek and Yavuz (2005). In these findings, individuals living in metropolitan cities were found to have higher self-esteem than those living in villages and towns.

In our study results, it is thought that the concepts such as the place of residence variable's having no impact on the participants' self-esteem levels, psychological and socio-economic factors in developing self-esteem, human relations, and the status of the community can be more important. Moreover, the diversity of transportation facilities today and the fact that people are constantly on the move for reasons such as work, education and travel can bring about this result.

No significant relationship was found between the self-esteem levels of the research group and the high school type of graduation variable. According to this result, it can be said that the high school type that the participants graduated does not have an effect on their self-esteem levels. When similar studies are examined, the results of the research conducted by Demir, Gürsoy, and Ada (2011); Görgen, Deniz, and Kiriş (2011) and Karaca., Akyol, L., and Can (2016) support our findings.

The fact that the high school type of the students appeals to their goals and expectations, the schools contribute positively to the personal development of the participants, and also the candidates participating in special talent exam are aware of their talents can be said to be the reason why the participants' self-esteem levels did not differ according to the type of school.

According to the relationship between self-esteem levels and sport branch variable, it has been observed that self-esteem levels of the candidates with no branch are higher than those doing team sports and individual sports. According to this result, it can be said that doing sports has no effect on the level of self-esteem and even candidates who do not do sports have higher self-esteem. In the literature review, no studies similar to our findings were found when studies similar to our research were examined. However, Bingöl and Alpkaya (2016); Tozoğlu, Bayraktar, Aka., and Tatlısu (2014); Gacar and Yanlıç (2012); Karakaya et al. (2006); Salokun (1990) concluded in their research findings that self-esteem levels of individuals who do sports have higher scores than those who do not do sports. Uçan and Cağlayan (2012); Mekolichick (2001) on the other hand, did not find any significant difference between the self-esteem of individuals who do and do not do sports.

Accordingly, self-esteem levels can be expected to be higher than those who do not do sports considering the fact that sports enable individuals to get to know themselves and to realize their potential and their self-esteem increases as they achieve success. It can be thought that the reason for the opposite result with our finding with this result is due to the characteristic of the sample group.

In conclusion, it has been found that there is no significant relationship between self-esteem levels of the candidates participated in special talent exam and gender variable, TYT (Basic Proficiency Test) score variable, geographical region of residence variable and high school type of graduation variable. However, a positive low level significant relationship has been found between self-esteem levels of the candidates and sport branch variable. 


\section{References}

Altunbaş, C. (2006). Examining the relationship between self-esteem levels and academic achievements of physical education and sports high school students. Unpublished Master Thesis, Cumhuriyet University, Institute of Health Sciences, Sivas.

Arseven, A. D. (1986). Self design (Relationship Between School Development and Success) (pp. 15-26). Ankara: Hacettepe University Faculty of Education Journal.

Aslan, H. (2006). Depression, self-esteem and locus of control perception variables according to job satisfaction levels. Unpublished Master Thesis. Ankara: Ankara University, Institute of Social Sciences.

Baybek, H., \& Yavuz, S. (2005). Investigation of self-esteem of Muğla university students. Journal of Social and Humanities Researches, 1(14), 73-95.

Bingöl, C., \& Alpkaya, U. (2016). The investigation of the self - esteem level of the athletes and non-athletes in high school students. Marmara University Journal of Sport Science, 1(1), 131-137.

Cengil, M. (2009). Hitit university theology faculty. examining the self-esteem levels of students in terms of various variables. Hitit University Faculty of Theology, 1(8), 77-102.

Ciğdemoğlu, S. (2006). Peer Pressure, self-esteem and extroversion personality traits of high school first year students according to school types. Master Thesis. Ankara University, Institute of Educational Sciences, Ankara.

Coopersmith, S. (1967). The antecedents of self-esteem. San Francisco: W.H. Freeman and Company.

Crocker, J., \& Major, B. (1989). Social stigma and self-esteem: The self-protective properties of stigma. Psychological Revierw, 96(4), 608630.Available at: https://doi.org/10.1037/0033-295x.96.4.608.

Cuhadaroğlu, F. (1986). Self-Esteem in adolescents. Unpublished Specialization Thesis, Hacettepe University Faculty of Medicine, Department of Psychiatry, Ankara.

Demir, V., Gürsoy, F., \& Ada, S. (2011). Examination of pre-service teachers' professional self-esteem. Gaziantep University Journal of Social Sciences, $10(1), 597-614$.

Gacar, A., \& Yanlıç, N. (2012). Investigation of self-esteem levels of adolescent handball players aged 13 - 17 in terms of some variables. Journal of Sports and Performance Research, 3(2), 45-50.

Görgen, İ., Deniz, S., \& Kiriş, A. (2011). Investigation of problem solving skills of prospective teachers of education. e-Journal of New World Sciences Academy, 6(1), 673-681.

Güçray, S. S. (2001). Relationship between decision making behaviors and self-esteem and problem solving skills perception in adolescents. Journal of Çukurova University Institute of Social Sciences, 8(8), 106-121.

Güloğlu, B., \& Aydın, G. (2001). Factor structure of Coopersmith self-esteem inventory. Education and Science, 26 (122), 66-71.

Inanç, N. (1997). Examining the relationship between university students' self-esteem levels and academic success. Unpublished Master Thesis. Gaziantep University Institute of Social Sciences, Gaziantep.

Karaca., N. H., Akyol, T., L., K., \& Can, Y., M. (2016). Examination of pre-service teachers' problem solving skills and self-esteem according to some variables. Afyon Kocatepe University Journal of Social Sciences, 18(1), 199-220.

Karakaya, I., Coşkun, A., \& A ğaoğlu, B. (2006). Evaluation of swimmers' depression, self-esteem and anxiety levels. Anatolian Journal of Psychiatry, 7(3), 162-166.

Karasar, N. (2005). Scientific research method (15th ed.). Ankara: Nobel Publishing.

Ko, C.-H., Yen, J.-Y., Chen, C.-C., Chen, S.-H., \& Yen, C.-F. (2005). Gender differences and related factors affecting online gaming addiction among Taiwanese adolescents. The Journal of Nervous and Mental Disease, 193(4), 273-277.Available at: https://doi.org/10.1097/01.nmd.0000158373.85150.57.

Kuzgun, Y. (2000). Vocational counseling. Ankara: Nobel Publishing.

Leung, L. (2004). Net-generation attributes and seductive properties of the internet as predictors of online activities and internet addiction. Cyber Psychology \& Behavior, 7(3), 333-348.Available at: https://doi.org/10.1089/1094931041291303.

Mekolichick, J. (2001). Self - esteem among amateur bodybuilders: A quantitative examination. Sociology of Sport Online, 4(2), 1-1 1.

O'Malley, P. M., \& Bachman, J. G. (1983). Self-esteem: Change and stability between ages 13 and 23. Developmental Psychology, 19(2), 257268.Available at: https://doi.org/10.1037/0012-1649.19.2.257.

Reisoğlu, I., Gedik, N., \& Göktaş, Y. (2013). The relationship between pre-service teachers' self-esteem and emotional intelligence levels with problematic internet use. Education and Science, 38(170), 150-165.

Rosenberg, M. (1965). Society and the adolescent self-Image. New Jersey: Princeton University Press.

Salmivalli, C., Kaukiainen, A., Kaistaniemi, L., \& Lagerspetz, K. M. (1999). Self-evaluated self-esteem, peer-evaluated self-esteem, and defensive egotism as predictors of adolescents' participation in bullying situations. Personality and Social Psychology Bulletin, 25(10), 1268-1278.Available at: https://doi.org/10.1177/0146167299258008.

Salokun, S. D. (1990). Comparision of nigerian high schoolathletes and nonathletes on self-concept. Perceptual and Motor Skills, 70(3), 865866.Available at: https://doi.org/10.2466/pms.1990.70.3.865.

Soner, O. (1995). Relationships between family cohesion, student self-confidence and academic success. Marmara University Institute of Educational Sciences, Ph.D. Thesis, Istanbul.

Tozoğlu, E., Bayraktar, G., Aka., S. T., \& Tatlısu, B. (2014). Studying the effects of sporting habits on the self-esteem of disabled individuals. Journal of Physical Education \& Sports Science, 8(2), 233-241.

Twenge, J. M., \& Campbell, W. K. (2002). Self-esteem and socioeconomic status: A meta-analytic review. Personality and Social Psychology Review, 6(1), 59-71.Available at: https://doi.org/10.1207/s15327957pspr0601_3.

Uçan, Y., \& Cağlayan, N. (2012). Comparison of self-esteem scores of individual and team sport athletes and non- athletes. Nigde University Journal of Physical Education And Sport Sciences, 6(3), 279-287.

Yenidünya., A. (2005). Competitive attitude, self-esteem and academic success in high school students. Marmara University Institute of Educational Sciences, Master Thesis, Istanbul.

Yılmaz, S. (2000). The relationship between self-esteem and assertiveness level of nursing school students. Unpublished Master Thesis, Atatürk University, Institute of Health Sciences, Erzurum. 